23. Рішення Конституційного Суду України від 5 квітня 2001 року № 3-рп/2001 у справі за конституційним поданням Президента України щодо відповідності Конституції України (конституційності) Закону України «Про внесення змін до деяких законодавчих актів України» (справа про податки). URL: http://zakon3.rada.gov.ua/laws/show/v003p710-01. (дата звернення: 12.02.2019).

24. Рішення Конституційного Суду України від 22 вересня 2005 року № 5-рп/2005 у справі за конституційним поданням 51 народного депутата України щодо відповідності Конституції України (конституційності) положень статті 92, пункту 6 розділу $\mathrm{X}$ «Перехідні положення» Земельного кодексу України (справа про постійне користування земельними ділянками). URL: http://zakon3.rada.gov.ua/ laws/show/v005p710-05 (дата звернення: 12.02.2019).

25. Рішення Конституційного Суду України від 13 березня 2012 року № 6-рп/2012 у справі за конституційним поданням 53 народних депутатів України щодо відповідності Конституції України (конституційності) пункту 2 частини першої статті 7, пункту 2 розділу VIII «Прикінцеві та перехідні положення» Закону України «Про засади запобігання і протидії корупції». URL: http:/zakon5.rada.gov.ua/ laws/show/v006p710-12 (дата звернення: 12.02.2019).

26. Конституція України від 28 червня 1996 року № 254к/96-ВР у редакції Закону України від 2 червня 2016 р. № 1401-VIII «Про внесення змін до Конституції України (щодо правосуддя)». Відомості Верховної Ради України. 2016. № 28. Ст. 532.

27. Ухвала Великої Палати Конституційного Суду України від 10 липня 2018 р. № 43-у/2018 про відмову у відкритті конституційного провадження у справі за конституційним поданням Верховного Суду України щодо відповідності Конституції України (конституційності) частини восьмої статті 36 Закону України «Про загальнообов'язкове державне соціальне страхування» у редакції Закону України «Про внесення змін до деяких законодавчих актів України щодо реформування загальнообов'язкового державного соціального страхування та легалізації фонду оплати праці». URL: http://zakon.rada.gov.ua/laws/show/v043u710-18 (дата звернення: 12.02.2019).

\title{
Berestova I. Competition of fundamental rights of persons in civil process: role of decisions of the constitutional court of Ukraine
}

The article is devoted to the study of the manifestation of competition and certain conflicts of constitutional values in civil proceedings. It is proved that the relationship between constitutional proceedings and civil proceedings is not directly regulated by law, but is under its influence (legal policy and legal culture). Together they form a complex subject of study of judicial law and economics, sociology and other non-legal sciences. It is substantiated that the constitutional values are lined up in a coherent hierarchical system, determine the presence of a certain constitutional balance between the structural elements of this system. To find such a balance in all cases is necessary exclusively through the prism of constitutional legal thinking. The position is upheld that the CCU emphasizes the social orientation of the state of Ukraine, the recognition of a person as the highest value in the state, which, in our opinion, manifests the social function of law.

Keywords: Constitutional Court of Ukraine, constitutional proceedings, civil proceedings, constitutional values, responsibility, retroactive responsibility, employer, article 58 of the Constitution of Ukraine

\section{ЗНАЧЕННЯ ТА РОЛЬ ПРАВИЛ ЕТИКИ У ДІЯЛЬНОСТІ АРБІТРІВ МІЖНАРОДНИХ КОМЕРЦІЙНИХ АРБІТРАЖІВ}

\author{
https://doi.org/10.32849/2409-9201.2019.19.4
}

\section{Гетманцев М. О.,}

кандидат юридичних наук, стариий науковий співробітник НДІ приватного права і підприсмництва імені академіка Ф. Г. Бурчака НАПрН України

Волощук О. T.,

кандидат юридичних наук, дочент, завідувач кафедри міжнародного та митного права Чернівецького юридичного інституту Національного університету «Одеська юридична академія»

У статті досліджується важливість дотримання арбітрами під час розгляду комериійних спорів в рамках міжнародних комериійних арбітражів, які є недержавними інституціями, етичних норм. В силу иього міжнародні арбітри та сторони в арбітражі мають розуміти як етика арбітра впливає на арбітражний розгляд $i$, в тому числі, на прочесуальні права та обов'язки сторін. Акцентовано увагу на необхідності розробки і прийнятті міжнародного кодексу етики, який би певною мірою уніфікував морально-етичні засади діяльності арбітрів. 
Ключові слова: арбітр, Міжнародний комерційний арбітраж, кодекс етики арбітрів, правила професійної етики, процесуальні права та обов'язки.

Протягом останніх десятиліть в багатьох країнах світу саме міжнародний комерційний арбітраж став основним засобом вирішення спорів у процесі здійснення зовнішньоекономічної діяльності, а постійно діючі міжнародні арбітражні суди набули авторитету та визнання. Таке відношення до цієї альтернативної форми вирішення спорів не в останню чергу пов'язується із тим, що арбітрами, які залучаються до вирішення комерційних спорів, виступають висококваліфіковані фахівці з беззаперечним авторитетом i визнанням як у наукових колах, так i в галузі торговельного обороту. Поряд iз сторонами арбітражного процесу арбітри $є$ центральними фігурами у галузі відправлення третейського судочинства. Арбітри володіють як відповідними знаннями, так і практичним досвідом. Чим досвідченіше арбітр, як вважається, тим краще він може здійснювати арбітражні функції, бути неупередженим, справедливим і чесним. Фактично результат арбітражного розгляду прямо залежить від арбітрів, їх компетентності, кваліфікованості, порядності, справедливості. Тому до кандидатур арбітрів часто пред'являються доволі високі вимоги, особливо, враховуючи недержавну природу міжнародного комерційного арбітражу, в плані відповідності морально-етичним нормам.

Безумовно, окреслена проблематика викликає інтерес науковців не тільки в плані дослідження правового статусу арбітра міжнародного комерційного арбітражу, а й щодо важливості дотримання етичних норм арбітрами при розгляді комерційних спорів. Зокрема, дослідження у цій галузі були здійснені такими науковцями, як: О. В. Брунцева, В. І. Гуменюк, О. С. Данилевич, М. Г. Єлісєєв, Н. Ю. Єрпильова, О. В. Казачков, О. С. Комаров, О. О. Костин, С. А. Курочкін, С. М. Лебедєв, Л. А. Лунц, В. А. Мусін, С. В. Ніколюкін, Ю. Д. Притика, М. О. Рожкова, О. Ю. Скворцов, Г. А. Цірат тощо. Водночас праці зазначених вчених носять узагальнюючий характер і в них детально не акцентується увага на морально-етичних вимогах до арбітрів.

Мета даної статті полягає у дослідженні морально-етичних засад діяльності арбітрів міжнародних комерційних арбітражів.

Кризові явища, пов’язані з розвитком існуючої цивілізації, глобальні проблеми, які на весь голос заявили про себе людству (екологічні, демографічні, проблеми війни і миру, голоду, хвороб, культури тощо), можуть бути вирішеними людьми з гуманістичними орієнтирами, які б прагнули будувати світ i своє життя на загальнолюдських моральних цінностях. За таких обставин зростає роль морального чинника в усіх сферах життєдіяльності суспільства і людини [1, с. 17].

У літературних джерелах доволі часто акцентується, що більшість видів трудової діяльності базується на моральній системі суспільства. Хоча потрібно вказати, що у ряді випадків це положення не є досить обгрунтованим, адже існує безліч професій, де такі поняття як обов'язок, совість, справедливість не є головними в професійній діяльності людини. Можна бути блискучим музикантом чи фізиком, неабияким інженером чи висококласним токарем $\mathrm{i}$, незважаючи на нестерпний $\mathrm{i}$ корисливий характер, користуватися репутацією відмінного фахівця. Приходячи в ці професії, люди не складають ніяких присяг, не створюють кодексів честі тощо. Тут головна роль належить таланту, вмінню, майстерності і працьовитості. Наприклад, норовливому і скандальному музиканту його відштовхуючі властивості не перешкоджають блискуче зіграти свою партію. Хто стане цікавитися особистими якостями кулінара, покуштувавши смачно приготовану їжу? Тут завжди на першому місці - професіоналізм.

Проте є професії, де моральний аспект відіграє основоположну роль (лікарі, вчителі, юристи, арбітри тощо). В названих сферах діяльності спостерігається особливо велика залежність однієї людини від іншої, і результати професійної діяльності можуть мати доленосне значення для інших людей. Відповідно до професіоналів, які займаються такою діяльністю, суспільство висуває не тільки вимоги загальної моралі (що стосуються будь-якої людини незалежно від професії), а і специфічні моральні вимоги. Більше того, моральність представника такої професії буде показником рівня професійності.

У цілому під етикою розуміється система універсальних і специфічних моральних вимог, і норм поведінки, що реалізуються в процесі життя. А під професійною етикою розуміють вчення про професійну мораль [2, с. 17]. Професійна етика, як і етика взагалі, виробляється поступово в процесі повсякденної спільної діяльності людей. Професійна етика систематизує накопичений в процесі історичної практики досвід, характерний для певного виду діяльності, узагальнює його і удосконалює у міру вдосконалення цього виду діяльності. Тому професійна етика може розглядатися як різновид загальної моралі, що має специфічні риси, обумовлені виглядом і типом діяльності, тобто $є$ прикладною науковою дисципліною, що вивчає професійну мораль. Водночас вона може розглядатися як прикладна теорія моральності, що існує в професійному середовищі [2, с. 22].

Це так званий кодекс правил, що визначає поведінку спеціаліста у службовій обстановці, норм, які відповідають існуючим законам та відомчим нормативним документам, професійним знанням, 
стосункам у колективі, глибокому усвідомленню моральної відповідальності за виконання професійних обов'язків. Це система конкретизованих моральних норм і принципів 3 врахуванням особливостей тої чи іншої професійної діяльності людей.

Крім традиційно відомих - медичної, педагогічної та юридичної, поряд 3 дипломатичною та військовою етикою, рішуче заявляють про себе адміністративна та депутатська етика, спортивна, етика вченого та журналіста. Постає питання: чи будь-яка професія вимагає специфічної професійної етики? Дедалі більш очевидним стає те, що прогресивний розвиток сучасного суспільства, усіх боків суспільного життя залежить від рівня загальноосвітньої та професійної підготовки, загальної культури, моральних якостей працівників - активних мислячих учасників історичної творчості. Кожна професія маю свою власну мораль. Професія формує у її носіїв не тільки професійні навики, а й певні риси особи і відношення до змісту своєї діяльності [2, с. 22].

Потрібно відмітити, що нині, коли у нашій країні дедалі більше утверджується ринкова економіка, частина бізнесменів, які беруть активну участь у тих чи інших комерційних проектах, звертаючись до міжнародного комерційного арбітражу, хотять бачити склад арбітрів, які $\epsilon$ не тільки висококваліфікованими спеціалістами у тій чи іншій галузі, але й відповідають певним моральним якостям. Хоча за кордоном це давно вже стало звичною практикою. Міжнародна спільнота, починаючи 3 другої половини минулого століття, доволі активно працює у цьому напрямку і не залишається осторонь. Слід відмітити, що багато міжнародних організацій пропонують свої кодекси професійної етики, у тому числі і щодо арбітрів міжнародних комерційних арбітражів. Крім цього, якщо подивитися на тематику конференцій, статей та документів 3 міжнародного арбітражу, то зрозуміло, що одним з найважливіших питань, які обговорюються, є питання етики в міжнародному арбітражі. На Віденських арбітражних днях та Арбітражному Дні Міжнародної асоціації адвокатів, які відбулися в березні 2011 року, це питання стояло в програмах дискусій. На думку Т. В. Сліпачук, розвиток міжнародної торгівлі, який тягне за собою зростання суперечок та непорозумінь, зумовлює динаміку розвитку і міжнародного арбітражу, створення в багатьох країнах національних арбітражних центрів, i, більш того, значно ускладнюються і самі спори, в яких беруть участь, в тому числі, сторони 3 таких юрисдикцій, які ще не мають довгої історії та сталої культури міжнародного арбітражу [3].

В силу цього міжнародні арбітри та сторони в арбітражі мають розуміти як етика арбітра впливає на арбітражний розгляд, і в тому числі, на процесуальні права та обов'язки сторін. Сьогодні вже існують кодекси етики арбітрів, наприклад, в Міжнародному центрі розгляду спорів (ICDR) чи Американській арбітражній асоціації (АAА), чи певні правила щодо етики арбітрів, які розроблені арбітражними центрами в Мілані, Китаї, Москві та Каїрі. Всі вони при певній єдності підходів все ж таки відображають засади тої чи іншої правової культури $\mathrm{i}$, певною мірою, мають служити вирішенню тих проблем, які мають місце в юрисдикції.

До прикладу наведемо положення Кодексу етики для арбітрів при вирішенні комерційних спорів США [4]. Канон 1 передбачає такі положення: арбітр зобов'язаний підтверджувати чесність і справедливість арбітражного процесу; комерційний арбітраж $\epsilon$ важливим методом розв'язання багатьох спорів. Для того, щоб комерційний арбітраж був ефективним, широка громадськість повинна бути впевнена в чесному і справедливому проведенні арбітражного процесу. Тому арбітр несе відповідальність не тільки перед сторонами, але й перед самим арбітражним процесом і повинен дотримуватися високих моральних норм для ствердження чесності і справедливості арбітражного процесу. Відповідно, арбітр повинен визнати свою відповідальність перед громадськістю, перед сторонами, чиї права він визначатиме, і перед усіма учасниками процедури. Положення даного Кодексу повинні тлумачитися і застосовуватися для досягнення цих цілей, тобто чесність арбітражного процесу полягає у тому, що особа не може призначати сама себе арбітром. Можливо лише виказати про готовність служити цій якості; особи повинні погоджуватися на призначення їх арбітрами тільки в тому випадку, якщо вони зможуть оперативно брати участь в арбітражному процесі. Погоджуючись на призначення і виконуючи обов'язки арбітра, особа не повинна вступати ні в які фінансові, ділові, професійні, сімейні або громадські взаємини або проявляти фінансовий або особистий інтерес, що може перешкодити неупередженості або створити упередженість. Арбітри повинні бути справедливими по відношенню до усіх сторін процесу і не повинні піддаватися тиску ззовні, протестам громадськості, впливу сторонньої критики чи особистим інтересам. Коли повноваження арбітра визначаються угодою сторін, він не повинен перевищувати ці повноваження або обмежувати їх. Якщо угода визначає процедуру арбітражу або правила його проведення, арбітр зобов'язаний слідувати цій процедурі або цим правилам; арбітр зобов'язаний робити все можливе для запобігання тактики затягування процесу, переслідування сторін або інших учасників, погроз, зловживання процесом або припинення арбітражного процесу [4].

Як видається, виконання арбітром вимог етичних норм повинно тривати не тільки від моменту призначення арбітражного розгляду, а й навіть після виконання своїх арбітражних функцій. Зрозуміло, що питання професійної етики має вагомий вплив на арбітраж. Вони стосуються не тільки 
незалежності та неупередженості арбітра, а й його свободи щодо вирішення окремих питань процесу. Крім того, вони мають значення і щодо рішення по суті спору.

3 нашої точки зору, міжнародний арбітраж є глобальним засобом вирішення спору і для його подальшого успішного розвитку необхідним є збереження високих стандартів саме у такому сенсі. Президент Української Арбітражної Асоціації, партнер, керівник практики міжнародного арбітражу юридичної фірми «Sayenko Kharenko» Тетяна Сліпачук вважає, що однією 3 ключових цілей Української Арбітражної Асоціації є саме пропаганда і поширення кращих стандартів етики в арбітражі: «Це важливо не тільки з точки зору виховання молодих юристів, практикуючих в арбітражі, але і з точки зору нашого іміджу на міжнародному рівні, а саме те, як ми будемо виглядати, сідаючи за стіл 3 представниками інших юрисдикцій» [3]. В цілому питання етики арбітрів $\epsilon$ доволі складними. На думку О. Бекетова, до причин, які ускладнюють визначення етики у міжнародному комерційному арбітражі, можна віднести: походження адвокатів сторін з різних правових систем, як наслідок - різність звичаїв та традицій при здійсненні своїх професійних обов'язків; відсутність кодексів поведінки адвокатів у міжнародному арбітражі, а, тим більше, відсутність регулювання етики у підготовці доказів у міжнародному арбітражі; відсутність наднаціонального органу по контролю за поведінкою адвоката та механізму санкцій за недотримання [6]. У якості прикладів недотримання загальноетичних норм у арбітражній практиці можна навести, зокрема, пред’явлення неповних документів та інших доказів (наприклад вибіркове надання судової практики чи окремої частини законодавства), невірного або викривленого на свою користь перекладу документів, копій документів у поганій якості, усвідомлене приховування інформації або ж навіть уникнення виконання наказів суду з приводу розкриття документів.

Варто погодитися, що на сьогодні нагальним $є$ питання про необхідність розробки і прийняття міжнародного кодексу етики, який би певною мірою уніфікував морально-етичні засади діяльності арбітрів. Навряд створення такого кодексу автоматично вирішить всі проблеми, але мабуть дозволить більш вимогливо сторонам обирати арбітрів, а самим арбітрам - ставитись сумлінно до своїх обов'язків. Але з іншого боку, розробка такого кодексу має певні ризики, в тому числі і щодо його неправильного застосування та тлумачення, наприклад, національними судами в процесі оспорювання чи виконання арбітражних рішень [7].

Мабуть дискусія щодо необхідності впровадження цього документа буде тривати ще не один рік. Хотілося, щоб і українські фахівці, які вже роблять перші кроки у цьому напрямку, взяли активну участь і в подальшому. Адже, як слушно відмітив з цього приводу В. Яременко «для правильного розвитку арбітражу в Україні важливо однакове розуміння і дотримання представниками сторін $\mathrm{i}$ арбітрами правил професійної етики. В іншому випадку арбітраж втратить ті переваги, які йому властиві, і нічим не буде відрізнятися від судових розглядів в Україні, в яких більш ніж достатньо випадків зловживання правами» [5].

Висновки. Отже, на підставі вищенаведеного можна з упевненістю констатувати важливість дотримання арбітрами під час розгляду комерційних спорів в рамках міжнародних комерційних арбітражів, які є недержавними інституціями, етичних норм. Більше того, етичні правила мають поширюватись не тільки на арбітрів, а й на інших учасників арбітражного процесу, як видається, це безумовна необхідність для представників сторін в арбітражі, оскільки їх наявність і дотримання сторонами збільшує його цінність і інтерес.

\section{СПИСОК ВИКОРИСТАНОЇ ЛІТЕРАТУРИ:}

1. Тофтул М. Г. Етика: навч. посіб. К.: ВЦ «Академія», 2006. 416 с.

2. Бралатан В. П., Гуралецко Л. В., Здирко Н. Г. Професійна етика. Навч. посіб. К.: Центр учбової літератури, 2011. $251 \mathrm{c}$.

3. Слипачук T. В. Вопросы этики в международном арбитраже. URL: https://studfiles.net/preview/ 6189977/page:46/ (дата звернення: 27.11.2018).

4. Кодекс этики для арбитров при разрешении коммерческих споров (CШA). URL: http://mosmediator.narod.ru/index/0-360 (дата звернення: 28.11.2018).

5. Юристы «за чашечкой кофе» обсудили вопросы профессиональной этики в арбитраже. URL: http://jurliga.ligazakon.ua/news/2013/3/13/85455.htm (дата звернення: 28.11.2018).

6. Бекетов О. Етичні принципи підготовки доказів в міжнародному комерційному арбітражі.

URL: http://www.uba.ua/documents/doc/beketov.pdf (дата звернення: 29.11.2018).

7. Слипачук T. В. Вопросы этики в международном арбитраже. URL:https://www.sk.ua/sites/default/ files/pitannya_etiki_v_mizhnarodnomu_arbitrazhi_yug_lyutiy_2011_1.pdf (дата звернення: 27.11.2018). 
Voloshchuk O., Getmantsev M. Value and role of ethics rules in the activities of arbitrators of international commercial arbitration.

The article examines the importance of compliance by arbitrators when considering commercial disputes within the framework of international commercial arbitrations, which are non-state institutions, ethical norms. As a result, international arbitrators and parties to arbitration should understand how the arbitrator's ethics affects arbitration proceedings, including procedural rights and obligations of the parties. The emphasis is placed on the necessity of developing and adopting an international code of ethics that would unify the moral and ethical principles of the work of arbitrators to a certain extent.

Key words: arbitrator, international commercial arbitration, code of ethics of referees, rules of professional ethics, procedural rights and obligations.

\title{
ПРИНЦИП СПРАВЕДЛИВОСТІ У ЦИВІЛЬНО-ПРАВОВИХ ЗОБОВ'ЯЗАННЯХ
}

\author{
https://doi.org/10.32849/2409-9201.2019.19.5
}

\section{Калаур I. P.,}

доктор юридичних наук, професор, старший науковий співробітник відділу проблем договірного права НДІ приватного права і підприємниитва імені академіка Ф. Г. Бурчака НАПрН України

\section{Зайцева-Калаур I. В.,}

кандидат юридичних наук, доцент, дочент кафедри економічної безпеки та фінансових розслідувань Тернопільського національного економічного університету

Розглянуто тенденції доктрини иивільного права та судової практики до з'ясування сутності принцииу справедливості у цивільному праві. Запропоновано розглядати зміст иього принципу у сфері цивільно-правових зобов 'язань крізь призму набуття суб' 'ктивних прав їх здійснення та захисту.

Ключові слова: принципи цивільного права, принцип справедливості, начало права, відшкодування моральної шкоди, неустойка.

Постановка наукової проблеми та їі значення. Розробники Цивільного кодексу України (далі ЦК України), визначивши загальними засадами вітчизняного цивільного законодавства справедливість, добросовісність та розумність, не витлумачили у кодифікованому акті цивілістичну сутність кожної iз них, поклавши у такий спосіб вирішення цього питання на науку цивільного права та судову практику. Втім, вітчизняна наука цивільного права сьогодні не виробила єдиних підходів до тлумачення змісту, розкриття взаємної залежності і взаємного зв'язку цих принципів. Останні дослідження вказаної проблематики були зроблені в наукових працях І. Г. Бабич «Принцип справедливості в римському праві і у сучасному зобов’язальному праві України», Ю. А. Тобота «Принцип справедливості, добросовісності і розумності в цивільному праві», Ю. В. Цюкало «Принципи здійснення цивільних прав».

Мета і завдання статті. Метою наукової роботи є з'ясування сучасних тенденцій до розкриття змісту принципу справедливості у доктрині цивільного права та судовій практиці.

Виклад основного матеріалу й обгрунтування отриманих результатів дослідження. Право $\epsilon$ мистецтвом справедливості [1]. Вперше категорія справедливість разом 3 двома іншими добросовісність і розумність - були визначені як загальні засади цивільного законодавства України у ст. 3 ЦК України. Україна єдина з-поміж інших держав, утворених на пострадянському просторі, визначила всю тріаду категорій принципами регулювання майнових і особистих немайнових відносин. Для прикладу, у ст. 2 Цивільного кодексу Республіки Білорусь [2] до основних засад цивільного законодавства включені лише добросовісність і розумність. Діяти добросовісно в процесі встановлення, здійснення і захисту цивільних прав та виконання цивільних обов'язків - так зумовлює законодавець, моделюючи у ст. 1 Цивільного кодексу Російської Федерації, основні засади цивільного законодавства [3]. Водночас у Цивільному кодексі Республіки Казахстан [4] такі категорії взагалі не визначені основними засадами, проте імперативно встановлено, що громадяни і юридичні особи повинні діяти, здійснюючи належні їм права, не тільки добросовісно, а й розумно та справедливо.

Об’єктивація цих принципів у кодифікованому акті, зауважують розробники проекту ЦК України, має велике значення для функціонування всієї системи приватного права, тому що вони: поперше, акумулювали в собі не тільки наведені вище засади, а й інші принципи цивільного права; подруге, застосування всіх інших принципів цивільного права не має призводити до несправедливого, нерозумного та недобросовісного результату; по-третє, саме ці принципи є основною сутністю права та вказують на його природне походження $[5,8]$, адже крізь призму природного принципу 